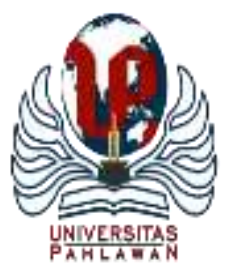

Edukatif : Jurnal Ilmu Pendidikan Volume 4 Nomor 1 Tahun 2022 Halm 984 - 992 EDUKATIF: JURNAL ILMU PENDIDIKAN

Research \& Learning in Education

https:/ledukatif.org/index.php/edukatif/index

\title{
Pengenalan BASF Virtual Lab Sebagai Media Pembelajaran Berbasis Technological Pedagogical Content Knowledge: Sebuah Survei Kepuasaan Guru Sekolah Dasar
}

\author{
Dyah Aniza Kismiati ${ }^{1 凶}$, Leonard R. Hutasoit ${ }^{2,}$ Ucu Rahayu $^{3}$ \\ Program Studi Pendidikan Biologi, Universitas Terbuka, Indonesia ${ }^{1,2,3}$ \\ E-mail : ㅁyah.aniza@ecampus.ut.ac.id ${ }^{1}$, leonard rh@ecampus.ut.ac.id ${ }^{2}, \underline{\text { urahayu} @ e c a m p u s . u t . a c . i d ~}^{3}$
}

\begin{abstract}
Abstrak
Kegiatan pembelajaran di masa pandemi memberikan tantangan tersendiri khususnya bagi para guru di Sekolah Dasar (SD) sebab guru harus memiliki beragam pengetahuan dan wawasan dalam menggunakan berbagai media pembelajaran. Oleh karena itu, pelatihan pengenalan media pembelajaran, terlebih pada media pembelajaran virtual sangat dibutuhkan. Penelitian ini merupakan penelitian survei yang bertujuan untuk mengetahui kepuasan dan kebermanfaatan dari pelatihan pengenalan media pembelajaran virtual BASF. BASF Virtual Lab merupakan sebuah platform dalam bentuk website yang dapat diakses oleh siapapun dan dimanapun secara gratis. Beragam fitur yang ada dalam BASF Virtual Lab potensial digunakan untuk membelajarkan IPA kepada siswa SD. Sebanyak 12 guru SD di Kota Tangerang Selatan mengikuti pelatihan ini. Sampel tersebut diperoleh dari Teknik pengambilan sampel secara random (acak). Data didapatkan melalui kuesioner berbentuk skala dengan rentang 1 hingga 5. Selanjutnya, data dianalisis secara deskriptif. Hasil penelitian menunjukkan bahwa mayoritas guru Sekolah Dasar (SD) yang mengikuti pelatihan pengenalan BASF Virtual Lab merasakan kepuasan yaitu sebanyak 58\% merasa sangat puas, $25 \%$ merasa puas dan $17 \%$ merasa biasa saja. Media BASF Virtual Lab juga dipandang menarik untuk dijadikan media pembelajaran IPA dengan tingkat kemenarikan 66,67\% sangat menarik dan 33,33 \% menarik. Media ini juga dirasakan kebermanfaatannya sebesar $75 \%$ sangat bermanfaat dan $25 \%$ bermanfaat.
\end{abstract}

Kata Kunci: media pembelajaran, virtual, guru SD, survei kepuasan

\begin{abstract}
Learning activities in the pandemic period provide their own challenges, especially for Teachers in Elementary School (SD). Teachers must have a wide range of knowledge and insights in using various learning media that can increase students' interest in online learning. Therefore, the training of the introduction of learning media, especially in virtual learning media is needed by teachers. This research is a survey study that aims to find out the satisfaction and benefits of basf virtual reality learning media introduction training. BASF Virtual Reality is a website platform that can be accessed by anyone and anywhere for free. Various features in BASF Virtual Reality are very potentially used to teach IPA to elementary school students. A total of 12 elementary school teachers in South Tangerang City participated in this training. The sample is obtained from the technique of sampling randomly (randomly). The data was obtained through a scaleshaped questionnaire with a range of 1 to 5. Next, the data is analyzed descriptively. The results showed that the majority of elementary school teachers who attended basf virtual lab recognition training felt satisfaction, which was $58 \%$ very satisfied, 25\% felt satisfied and 17\% felt ordinary. BASF Virtual Lab media is also seen as interesting to be used as an IPA learning media with a $66.67 \%$ mortality rate is very interesting and $33.33 \%$ interesting, and this media also feels its usefulness of $75 \%$ is very useful and $25 \%$ useful.
\end{abstract}

Keywords: learning media, virtual, elementary school teachers, satisfaction surveys.

Copyright (c) 2022 Dyah Aniza Kismiati, Leonard R. Hutasoit, Ucu Rahayu

$\triangle$ Corresponding author

Email : dyah.aniza@ecampus.ut.ac.id

DOI : https://doi.org/10.31004/edukatif.v4i1.1960

ISSN 2656-8063 (Media Cetak)

ISSN 2656-8071 (Media Online)

Edukatif : Jurnal Ilmu Pendidikan Vol 4 No 1 Tahun 2022 p-ISSN 2656-8063 e-ISSN 2656-8071 
985 Pengenalan BASF Virtual Lab Sebagai Media Pembelajaran Berbasis Technological Pedagogical Content Knowledge: Sebuah Survei Kepuasaan Guru Sekolah Dasar - Dyah Aniza Kismiati, Leonard R. Hutasoit, Ucu Rahayu

DOI: https://doi.org/10.31004/edukatif.v4i1.1960

\section{PENDAHULUAN}

Pandemi Covid 19 amat berdampak luas terhadap pembelajaran di dunia, termasuk di Indonesia. Pemerintah Indonesia pun memberikan instruksi kebijakan untuk kebijakan pelaksanaan pembelajaran daring.

Pembelajaran daring merujuk pada sistem pembelajaran yang dilakukan secara tidak langsung (tidak bertatap muka) tetapi menggunakan platform yang dapat membantu proses belajar mengajar yang dilakukan meskipun jarak jauh (Irinna Aulia Nafrin \& Hudaidah, 2021). Kebijakan pembelajaran daring ditegaskan dengan diterbitkannya Surat Edaran Kementerian Pendidikan dan Kebudayaan Indonesia Nomor 4 Tahun 2020 tentang Pelaksanaan Pendidikan Dalam Masa Darurat Covid-19 yang kemudian ditekankan dengan Surat Edaran Sesjen nomor 15 tahun 2020 tentang Pedoman Pelaksanaan BDR (Belajar Dari Rumah) selama darurat Covid-19. Adapun yang menyatakan bahwa tujuan Belajar dari Rumah (BDR) (Komang \& Astini, 2020) adalah untuk memenuhi standar pendidikan melalui pemanfaatan teknologi informasi dengan menggunakan perangkat komputer atau gadget yang saling terhubung antara siswa dan guru. Belajar dari rumah yaitu dengan sistem pembelajaran daring tentu bukanlah sesuatu hal yang mudah untuk dilakukan. Penyampaian materi secara daring tidak bisa dipahami oleh semua siswa. Menurut (Asmuni, 2020) dalam pembelajaran daring khususnya bagi pembelajaran di SD, guru mengalami kesulitan dalam mengontrol suasana belajar, hal ini disebabkan keterbatasan dalam ruang virtual. Belajar IPA melalui daring tentu bukanlah sesuatu yang mudah sebab dalam pembelajaran IPA di SD sebab sebagian besar materinya harus dilakukan melalui percobaan atau eksperimen yang membutuhkan bimbingan guru agar materi yang diajarkan akan tersampaikan dengan baik (Encep Andriana, Suci Ramadayanti, 2020). Hal ini karena hakikat IPA itu sendiri yang menurut Puskur dalam Kumala (2017) meliputi 3 unsur utama yaitu sikap, proses dan produk. Didalam pembelajaran IPA haruslah terjadi proses sains yang menghasilkan produk sains melalui eksperimen/ percobaan hingga dapat terbentuk sikap ilmiah. Cara Penyelidikan IPA menurut Wisudawati (2015) terdiri atas kegiatan observasi, eksperimen dan matematika. Observasi dilakukan ketika para ahli yang ingin mempelajari objek atau kejadian alam melalui ketiga kegiatan tersebut dengan menggunakan metode ilmiah. Proses pembelajaran IPA haruslah menekankan pada pemberian pengalaman secara langsung kepada siswa untuk mengembangkan kompetensi siswa agar dapat menjelajahi dan memahami alam sekitar. Dengan demikian, siswa akan dapat menemukan sendiri konsep materi pelajaran yang sedang dipelajarinya. Tak hanya itu pembelajaran IPA juga diarahkan untuk memberi pengalaman langsung yang dapat mendorong siswa untuk mendapatkan pemahaman yang lebih mendalam (Nupita, E. 2013).

Untuk dapat menjembatani hal tersebut dan menuangkannya dalam pembelajaran secara daring, maka guru membutuhkan beragam wawasan terkait media pembelajaran yang dapat memfasilitasi dan memberikan panduan kepada siswa. Oleh karenanya, pelatihan penggunaan media pembelajaran dibutuhkan oleh guru. Pelatihan penggunaan media pembelajaran dapat berbasiskan pada TPACK (Technological Pedagogical Content Knowledge) yang dapat diartikan sebagai kerangka pengetahuan bagi guru untuk mengembangkan pengalaman belajar bagi siswa dengan mengintegrasikan strategi penggunaan teknologi. Model Technological Pedagogical Content Knowledge memfasilitasi integrasi antara alat digital dan media dalam proses belajar mengajar mengingat aspek pedagogis, konten dan teknologi (Salas-Rueda, 2020). Adapun kerangka yang dimaksud menurut Koehler \& Mishra, 2009 adalah sebagai berikut: 


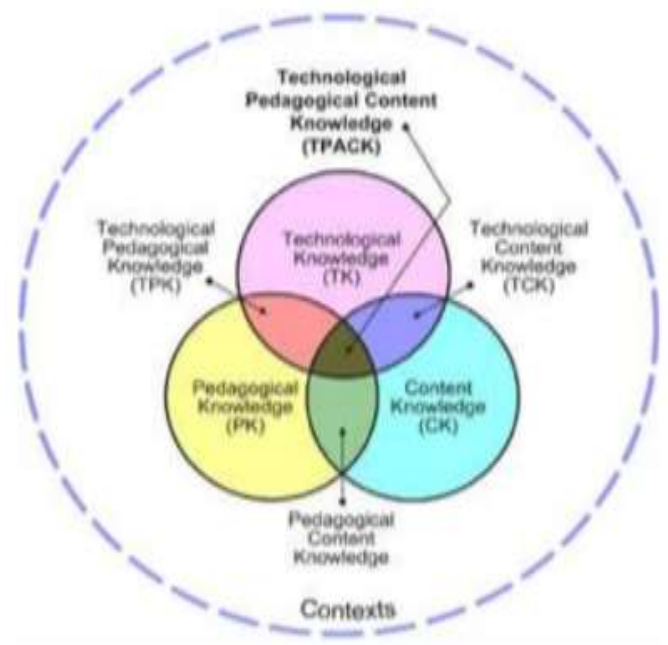

\section{Gambar 1. Kerangka Technological Pedagogical Content Knowledge}

Kegiatan mengajar yang dilakukan oleh guru, baik secara tatap muka maupun daring merupakan kegiatan kompleks yang melibatkan berbagai jenis pengetahuan, yang didasari dengan adanya pengetahuan tentang materi yang akan diajarkan (content knowledge), cara mengajarkan suatu materi (pedagogical knowledge), dan pengetahuan tentang penggunaan berbagai teknologi (technological knowledge) (Rahmadi, 2019). Hampir senada dengan pendapat Rahmadi, Content Knowledge (CK) mengacu pada topik yang diajarkan di kelas, Pedagogical Knowledge (PK) mengacu pada metode pengajaran yang juga meliputi: pengetahuan tentang manajemen dan organisasi kelas; analisis dan perencanaan kurikuler; dan pembelajaran siswa (Roig-vila et al., 2015). Pengetahuan Teknologi (TK) mengacu pada penggunaan TIK di bidang pendidikan (Brantley-dias, 2014).

Selain Content Knowledge (CK), Pedagogical Knowledge (PK), dan Technological Knowledge (TK), juga terdapat Pedagogical Content Knowledge (PCK), Technological Content Knowledge (TCK), Technological Pedagogical Knowledge (TPK). Pedagogical Content Knowledge (PCK) mengacu pada apa yang digunakan untuk mengajarkan isi kursus, Pengetahuan Konten Teknologi (TCK) mengacu pada penggunaan teknologi untuk mengirimkan materi pembelajaran dan Pengetahuan Pedagogis Teknologi (TPK) mengacu pada penggunaan teknologi dalam konteks pendidikan (Almenara et al., 2017). Komponenkomponen tersebutlah yang dapat mendukung suatu kegiatan mengajar dapat terlaksana dan tersampaikan dengan baik. Merujuk pada tantangan pembelajaran IPA secara daring saat ini, maka komponen technological knowledge adalah hal yang sepatutnya disoroti dan dilatihkan kepada para guru. Salah satu bentuk teknologi yang dibutuhkan untuk dapat mengemas pembelajaran IPA di SD ini adalah penggunaan media virtual IPA kepada siswa SD. Pada saat ini, memang sudah mulai banyak media pembelajaran virtual yang ditawarkan untuk digunakan sebagai media pembelajaran di masa pandemik, namun lebih banyak sasaran penggunanya adalah siswa sekolah menengah dan juga mahasiswa. Sayangnya, untuk siswa sekolah dasar, penggunaan media pembelajaran virtual untuk mata pelajaran IPA belum banyak dikenalkan oleh karena oleh faktor seperti belum terbiasanya siswa Sekolah Dasar untuk menggunakan platform pembelajaran online, dukungan orang tua, rumitnya penggunaan platform media pembelajaran, kemahiran siswa dalam menggunakan gadget untuk pembelajaran (Kurniawati, 2020) dan beberapa hal lainnya. Oleh karena itu penelitian ini penting untuk dilakukan untuk mengetahui adanya perbaikan pelatihan pengenalan media pembelajaran virtual. 
987 Pengenalan BASF Virtual Lab Sebagai Media Pembelajaran Berbasis Technological Pedagogical Content Knowledge: Sebuah Survei Kepuasaan Guru Sekolah Dasar - Dyah Aniza Kismiati, Leonard R. Hutasoit, Ucu Rahayu

DOI: https://doi.org/10.31004/edukatif.v4i1.1960

\section{METODE PENELITIAN}

Penelitian ini adalah penelitian deskriptif dan merupakan sebuah survei kepuasan dari pelatihan pengenalan BASF Virtual Lab Sebagai Media Pembelajaran Berbasis TPACK (Tehnological Pedagogical Content Knowledge). Pelatihan pengenalan BASF Virtual Lab diikuti oleh sebanyak 12 orang guru IPA SD di Kota Tangerang Selatan. Pemilihan sampel ini menggunakan teknik pengambilan sampel secara acak (random sampling). Adapun pengumpulan data yaitu melalui kuesioner kepuasaan yang diisikan oleh peserta diakhir sesi pelatihan yang berupa rentang nilai kepuasan dari nilai terendah (1=tidak puas) hingga nilai tertinggi ( $5=$ sangat puas). Data yang diperoleh lalu dianalisis secara deskriptif dan dituangkan dalam bentuk diagram.

\section{HASIL DAN PEMBAHASAN PENELITIAN}

\section{Sebaran Peserta Pelatihan Pengenalan BASF Virtual Lab}

Pelatihan pengenalan BASF Virtual Lab telah dilakukan kepada guru SD di Kota Tangerang Selatan yaitu berjumlah 12 orang guru IPA (termasuk guru tematik). Adapun deskripsi partisipan (peserta) ditunjukkan pada Tabel 1 berikut ini.

Tabel 1. Informasi Data Partisipan

\begin{tabular}{llll}
\hline Inisial & Jenis Kelamin & Status & $\begin{array}{l}\text { Latar Belakang } \\
\text { Pendidikan }\end{array}$ \\
\hline G1 & Wanita & Guru Wali Kelas 6 & S1-PGSD \\
\hline G2 & Laki-laki & Guru Wali Kelas 5 & S1-PGSD \\
\hline G3 & Wanita & Guru Wali Kelas 2 & S1-PGSD \\
\hline G4 & Wanita & Guru Wali Kelas 4 & S1-PGSD \\
\hline G5 & Laki-laki & Guru Wali Kelas 5 & S1-PGSD \\
\hline G6 & Wanita & Guru Wali Kelas 5 & S1-PGSD \\
\hline G7 & Wanita & Guru Wali Kelas 6 & S1-PGSD \\
\hline G8 & Laki-laki & Guru Wali Kelas 6 & S1-PGSD \\
\hline G9 & Wanita & Guru Wali Kelas 2 & S-1 PKn \\
\hline G10 & Laki-laki & Guru Wali Kelas 5 & S1-PGSD \\
\hline G11 & Wanita & Guru Wali Kelas 5 & S1-PGSD \\
\hline G12 & Wanita & Guru Wali Kelas 2 & S1-PGSD
\end{tabular}

Berdasarkan deskripsi partisipan tersebut, sebagian besar partisipan lebih didominasi oleh guru wanita, dan hampir semua guru memiliki latar belakang Pendidikan yang sama yaitu Sarjana Pendidikan Guru Sekolah Dasar, meskipun salah satu diantaranya merupakan guru PKn yang mengampu pelajaran tematik di jenjang kelas 2 Sekolah Dasar (SD). Dari sejumlah partisipan tersebut 3 diantaranya merupakan guru kelas bawah (kelas 1-3 SD), sedangkan 9 diantaranya merupakan guru SD kelas atas (kelas 4-6 SD).

\section{Pengenalan BASF Virtual Lab}

Pada hakikatnya, pembelajaran IPA merupakan pembelajaran yang terdiri atas kumpulan informasi mengenai gejala alam yang telah ditentukan kebenarannya (Kenedi, 2017). Lebih lanjut, pembelajaran IPA merupakan pembelajaran yang berkaitan dengan alam. Menurut Astimar (2019) pembelajaran IPA dengan menggunakan lingkungan alam diperlukan sebagai sumber pembelajaran yang berdampak bagi siswa akan aktif, memotivasi, antusiasme dan minat belajar. Dengan menggunakan lingkungan alam maka akan membantu siswa untuk memahami konsep makhluk hidup dan lingkungan serta karakteristik lingkungan yang baik, sebab makhluk hidup itu sendiri sering ditampilkan dan dimanfaatkan dalam kehidupan sehari-hari. 
988 Pengenalan BASF Virtual Lab Sebagai Media Pembelajaran Berbasis Technological Pedagogical Content Knowledge: Sebuah Survei Kepuasaan Guru Sekolah Dasar - Dyah Aniza Kismiati, Leonard R. Hutasoit, Ucu Rahayu

DOI: https://doi.org/10.31004/edukatif.v4i1.1960

Pembelajaran, juga seharusnya dilakukan dengan menyesuaikan karakter pembelajaran, dalam hal ini adalah siswa Sekolah Dasar. Siswa sekolah dasar merupakan siswa yang berada pada masa operasional kongkret sehingga membutuhkan pembelajaran nyata sebagai upaya membelajarkan siswa sekolah dasar (Kiswanto, 2017). Mengingat situasi dan kondisi pandemi pada saat ini, maka guru harus menerapkan metode yang inovatif dan menyenangkan, seperti penggunaan media pembelajaran BASF Virtual Lab. Pelatihan pengenalan BASF Virtual Lab dilakukan pada bulan Agustus 2021 dengan jumlah peserta 12 orang guru SD di Kota Tangerang Selatan. Berdasarkan hasil wawancara singkat kepada para peserta, mayoritas semua peserta mengeluhkan kesulitan dalam melakukan pembelajaran IPA ketika masa pandemik. Pembelajaran IPA menjadi kurang efektif karena kurang beragamnya media pembelajaran yang digunakan yang dapat menarik minat siswa untuk belajar di rumah. Terlebih lagi, ketika sistem Belajar dari Rumah (BDR) dilakukan, maka para guru dan juga orang tua pun mengeluhkan hal yang relatif sama.

BASF Virtual Lab merupakan sebuah platform laboratorium virtual yang dikembangkan oleh BASF Company yang berpusat di Jerman. BASF Virtual Lab diciptakan dengan harapan terhadap masa depan bahwa para siswa merupakan innovator dan pemimpin masa depan. BASF Virtual Lab merupakan media pembelajaran yang interaktif, menyenangkan, dan gratis yang dirancang untuk anak-anak berusia 6 hingga 12 tahun untuk berkenalan dengan dunia IPA (Sains) melalui eksperimen sederhana secara virtual. Platform ini dibuat dalam situs website dan menyediakan alih bahasa seperti Bahasa inggris, jerman, china, Bahasa Indonesia, portugis, perancis dan lain sebagainya. Di dalam BASF Virtual Lab terdapat fitur-fitur menu seperti yang ditunjukkan dalam Gambar 2 berikut ini:

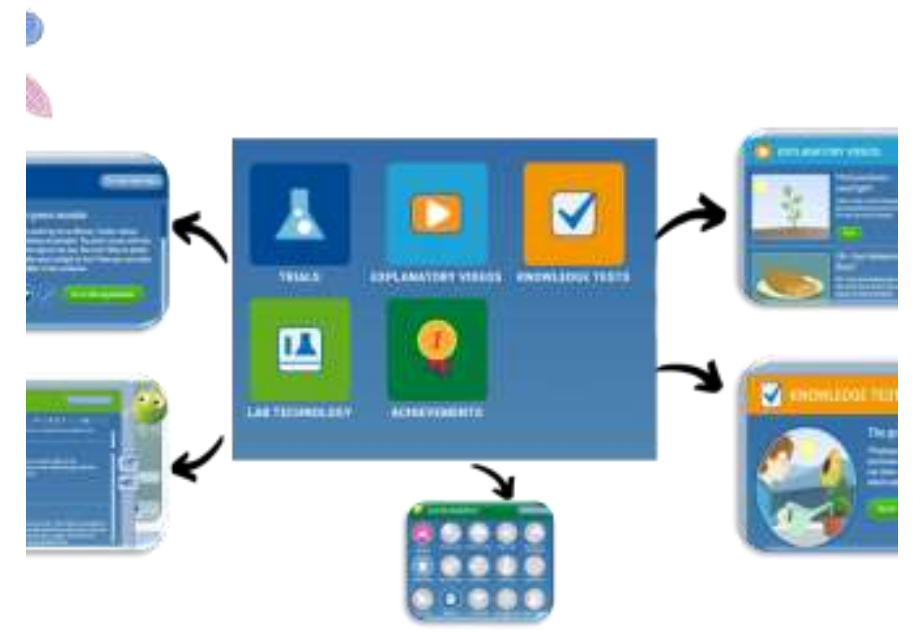

\section{Gambar 2. Tampilan Fitur Dalam BASF Virtual Lab}

Fitur yang pertama adalah menu Trial atau Eksperimen yang berisi tuntunan percobaan terkait sub tema yang dipilih. Pada dasarnya, kegiatan pembelajaran eksperimen harus dilaksanakan dalam pembelajaran sains dimana untuk itu membutuhkan ruang laboratorium. Oleh karena situasi pandemi pada saat ini maka sebagai alternatif, dapat menggunakan laboratorium virtual (Tuhusula et al., 2020) sebab pembelajaran sains atau IPA melalui eksperimen baik itu secara simulasi ataupun langsung dapat berpengaruh terrhadap meningkatnya pemahaman belajar siswa (Theasy et al., 2021). Untuk materi IPA SD dapat memilih sub tema The Green Wonder atau dalam menu bahasa indonesia dikenal sebagai Keajaiban Si Hijau . Pada sub tema ini berisikan tentang materi fotosintesis pada tumbuhan. Trial atau ekperimen yang diberikan menjelaskan proses yang terjadi dalam fotosintesis, zat-zat apa yang dibutuhkan dan juga zat yang pada akhirnya diproduksi. Penjelasan mengenai proses fotosintesis ini secara sederhana akan dijabarkan dalam fitur Explanatory Videos atau Video Penjelasan. Video ini dibuat secara sederhana untuk memberikan pemahaman konsep kepada siswa SD dan dibuat menarik untuk menumbuhkan minat siswa. Fitur selanjutnya yang ada dalam BASF Virtual Lab adalah 
fitur Lab Technologi yang berisi pengenalan nama dan fungsi peralatan laboratorium. Fitur ini dapat membiasakan siswa untuk mengenal jenis-jenis peralatan laboratorium sedari ini. Siswa diperkenalkan dengan nama alat, bentuknya, sifat bahannya serta fungsi-fungsinya. Hal ini mencakup pengenalan pembelajaran IPA di SD yang memiliki beragam manfaat diantaranya: membangkitkan motivasi belajar, mengembangkan keterampilan dasar melakukan eksperimen, menjadi wahana belajar pendekatan ilmiah dan menunjang materi pelajaran (Sekaringtyas, 2017).

Lab technology dikemas dalam bentuk permainan menjodohkan (matching game), apabila siswa salah menjodohkan peralatan dengan fungsinya maka akan peralatan tersebut tidak akan bisa diambil, sehingga siswa harus paham nama, bentuk dan fungsi peralatan dengan benar. Fitur yang selanjutnya adalah Knowledge Test atau Tes Pengetahuan. Tes adalah rangkaian tugas dalam bentuk soal atau perintah yang harus dikerjakan oleh siswa, dimana hasilnya akan digunakan untuk menarik kesimpulan-kesimpulan tertentu terhadap siswa (Asrul, Rusydi Ananda, 2015). Tes merupakan suatu bentuk alat evaluasi untuk mengukur seberapa jauh tujuan pengajaran telah tercapai,jadi berarti evaluasi terhadap hasil belajar (Kadir, 2015). Tes memiliki beragam bentuk. Salah satu bentuk tes hasil belajar adalah tes pilihan ganda.Tes pilihan ganda adalah bentuk tes obyektif yang mempunyai ciri utama kunci jawaban jelas dan pasti sehingga hasilnya dapat dinilai secara obyektif. Didalam fitur ini, siswa akan mengerjakan sejumlah butir tes pilihan, dan akan terdapat klarifikasi jawaban yang diberikan oleh sistem. Fitur terakhir yang ada didalam BASF Virtual Lab adalah Achievement (prestasi). Didalam menu ini, siswa dapat melihat prestasi yang mereka capai setelah mengikuti pembelajaran dalam BASF Virtual Lab. Reward atau hadiah dari prestasi ini berupa poin dan bintang. Menurut Raihan (2019), 'Reward' (ganjaran) merupakan salah satu alat pendidikan yang berguna untuk mempergiat usaha siswa untuk mempertinggi prestasi yang telah atau akan dicapai, sedangkan menurut (Subakti et al., 2020), reward disebutkan sebagai penghargaan yang diberikan kepada siswa untuk menarik minat belajar siswa dengan harapan untuk meningkatkan hasil atau prestasi siswa. Pelatihan pengenalan BASF Virtual Lab sebagai media pembelajaran pada pelatihan TPACK pada guru SD di Kota Tangerang Selatan mendapatkan banyak respon positif, seperti yang ditunjukkan dalam Gambar 3 berikut.

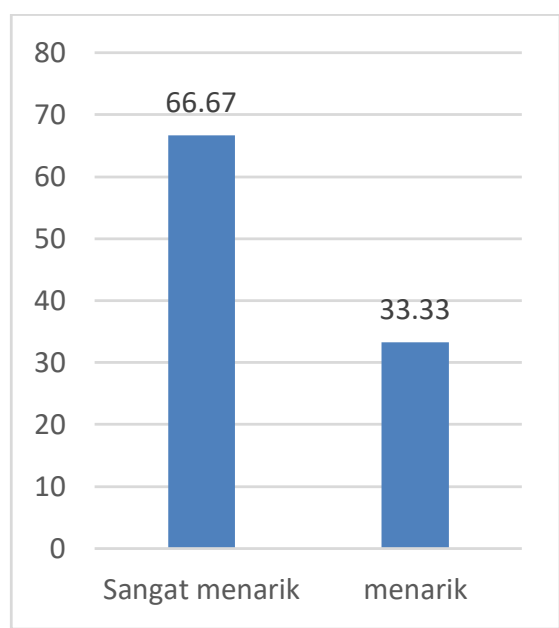

\section{Gambar 3. Respon Guru SD di Kota Tangerang Selatan Terhadap Kemenarikan Media Pembelajaran BASF Virtual Lab}

Berdasarkan Gambar 3 tersebut terlihat antusias peserta yang menyatakan bahwa BASF Virtual Lab menarik untuk digunakan sebagai media pembelajaran untuk siswa Sekolah Dasar (SD). Bila dilihat dari jenisnya, BASF Visual Lab merupakan jenis media pembelajaran audio visual dalam bentuk website. Jenis media seperti inilah yang disukai oleh banyak orang, terlebih untuk anak-anak. Kemenarikan media akan memungkinkan terciptanya situasi belajar yang menyenangkan, dan mendorong terbentuknya situasi belajar 
990 Pengenalan BASF Virtual Lab Sebagai Media Pembelajaran Berbasis Technological Pedagogical Content Knowledge: Sebuah Survei Kepuasaan Guru Sekolah Dasar - Dyah Aniza Kismiati, Leonard R. Hutasoit, Ucu Rahayu

DOI: https://doi.org/10.31004/edukatif.v4i1.1960

mengajar yang kondusif yang nantinya akan berpengaruh terhadap pemahaman konsep dalam belajar (Rosidah, 2016)

Selain untuk mengetahui tentang kemenarikan BASF Virtual Lab untuk dijadikan media pembelajaran, survei kepuasan ini juga digunakan untuk mengetahui kebermanfaatan pelatihan pengenalan BASF Virtual Lab yang terlihat dalam Gambar 4 berikut.

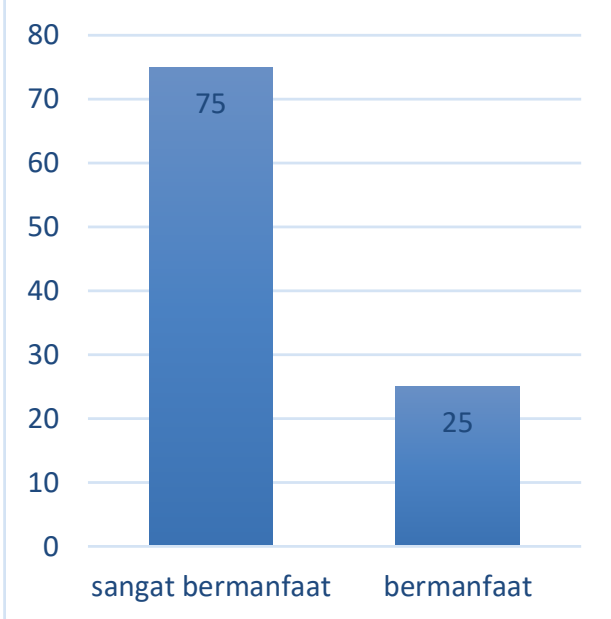

\section{Gambar 4. Kebermanfaatan Penggunaan BASF Virtual Lab Sebagai Media Pembelajaran}

Sebanyak 75\% guru SD di Kota Tangerang Selatan yang menjadi peserta menyatakan bahwa BASF Virtual Lab sangat bermanfaat untuk dijadikan media pembelajaran virtual, dan 25\% lainnya juga merasakan kebermanfaatannya. Manfaat penggunaan media virtual menurut Darmayanti (2016) dapat memberikan pengaruh yang signifikan terhadap hasil belajar siswa. Lebih lanjut, Darmayanti memaparkan bahwa peningkatan hasil belajar siswa menunjukkan bahwa penggunaan media virtual dalam pembelajaran akan memberikan kesempatan yang luas bagia siswa untuk terlibat langsung dalam proses pembelajaran dan membangun sendiri pengetahuannya. Penggunaan media media virtual juga mampu merangsang pikiran, kemauan, perhatian, dan perasaan siswa dalam suasana belajar yang menyenangkan sehingga materi yang disampaikan menjadi lebih jelas. Diakhir pelaksanaan pelatihan, juga terangkum data kepuasan peserta mengikuti pelatihan pengenalan BASF Virtual Lab sebagai media pembelajaran yang dapat dilihat pada Gambar 5.

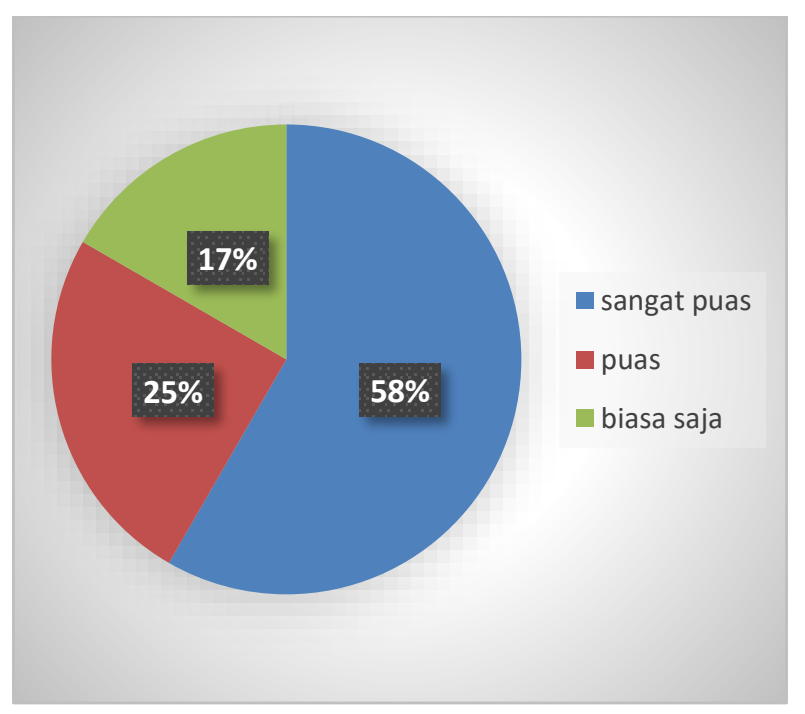

Gambar 5. Kepuasaan Pelatihan Pengenalan Penggunaan BASF Virtual Lab 
991 Pengenalan BASF Virtual Lab Sebagai Media Pembelajaran Berbasis Technological Pedagogical Content Knowledge: Sebuah Survei Kepuasaan Guru Sekolah Dasar - Dyah Aniza Kismiati, Leonard R. Hutasoit, Ucu Rahayu

DOI: https://doi.org/10.31004/edukatif.v4i1.1960

Survei menunjukkan bahwa mayoritas peserta pelatihan merasakan kepuasan setelah mengikuti pelatihan mengenalan BASF Virtual sebagai media pembelajaran IPA SD yakni sebanyak $58 \%$ merasa sangat puas, $25 \%$ merasa puas dan $17 \%$ merasa biasa saja. Pelatihan memang sangat dibutuhkan bagi para guru agar dapat menambah referensi dalam mengajar, terlebih di masa pandemi seperti saat ini dimana pembelajaran harus dilakukan secara daring (online) dengan segenap kendala yang selalu bermunculan. Adanya pelatihan juga akan meningkatkan profesionalitas guru. Guru yang profesional dan bermartabat akan melahirkan anak bangsa yang cerdas, kritis, inovatif, demokratis, dan berakhlak (Dudung, 2009). Pelatihan yang diajarkan juga bermanfaat untuk meningkatkan motivasi guru dalam bekerja ( (Yuliana, Haryadi, 2019)

\section{KESIMPULAN}

Berdasarkan hasil survei dan paparan dalam pembahasan, maka dapat disimpulkan bahwa: mayoritas guru Sekolah Dasar (SD) yang mengikuti pelatihan pengenalan BASF Virtual Lab merasakan kepuasan terhadap pelatihan pengenalan media pembelajaran BASF Virtual Lab yaitu sebanyak 58\% merasa sangat puas, 25\% merasa puas dan 17\% merasa biasa saja. Media BASF Virtual Lab juga dipandang menarik untuk dijadikan media pembelajaran IPA dengan tingkat kemenarikan 66,67\% sangat menarik dan 33,33\% menarik, serta media ini juga dirasakan kebermanfaatannya sebesar $75 \%$ sangat bermanfaat dan $25 \%$ bermanfaat. Hasil dari survei kepuasaan pelatihan ini dapat menjadi masukan dan perbaikan dalam menyelenggarakan pelatihan pengenalan media virtual, dan diharapkan para guru menggunakan media pembelajaran virtual yang dilatihkan sebagai sumber belajar siswa dalam belajar IPA di masa pandemik.

\section{DAFTAR PUSTAKA}

Almenara, J. C., Roig-Vila, R., \& Roig-Vila, R. (2017). Conocimientos Tecnológicos , Pedagógicos Y Disciplinares De Los Futuros Docentes Según El Modelo Tpack Technological, Pedagogical , And Content Knowledge Of Future Teachers According To The Tpack Model. Digital Education Review, 32, $73-84$.

Asmuni. (2020). Problematika Pembelajaran Daring Di Masa Pandemi Covid-19 Dan Solusi Pemecahannya. Jurnal Penelitian Dan Pengembangan Pendidikan, 7(4), 281-288. Http://Ojs.Ikipmataram.Ac.Id/Index.Php/Pedagogy/Index\%0aoktober

Asrul, Rusydi Ananda, R. (2015). Evaluasi Pembelajaran. Citapustaka Media.

Astimar, N. (2019). The Review Of Utilization In Natural Environment By The Teacher As A Source For Learning Science At Elementary School In Low Class The Review Of Utilization In Natural Environment By The Teacher As A Source For Learning Science At Elementary School In Low. Journal Of Physics: Conference Series. Https://Doi.Org/10.1088/1742-6596/1424/1/012036

Brantley-Dias, L. (2014). Goldilocks And Tpack. Journal Of Research On Technology In Education, February. Https://Doi.Org/10.1080/15391523.2013.10782615

Darmayanti. (2016). Penggunaan Media Virtual Interaktif Untuk Meningkatkan Hasil Belajar Siswa Pada Konsep Tekanan Di Kelas X Smk Negeri 5 Telkom Banda Aceh.

Dudung, A. (2009). Pelatihan Pengembangan Keprofesian Berkelanjutan ( Pkb ) Bagi Guru - Guru Se Jakarta Timur. 13-21.

Encep Andriana, Suci Ramadayanti, T. E. N. (2020). Pembelajaran Ipa Do Sd Pada Masa Covid 19. Prosiding Seminar Nasional Pendidikan Fkip, 3(1), 409-413.

Irinna Aulia Nafrin, \& Hudaidah. (2021). Perkembangan Pendidikan Indonesia Di Masa Pandemi Covid-19 Abstrak. Edukatif: Jurnal Ilmu Pendidikan, 3(2), 456-462. 
992 Pengenalan BASF Virtual Lab Sebagai Media Pembelajaran Berbasis Technological Pedagogical Content Knowledge: Sebuah Survei Kepuasaan Guru Sekolah Dasar - Dyah Aniza Kismiati, Leonard R. Hutasoit, Ucu Rahayu

DOI: https://doi.org/10.31004/edukatif.v4i1.1960

Kadir, A. (2015). Menyusun Dan Menganalisis Tes Hasil Belajar Abdul Kadir. Jurnal Al-Ta'dib, 8(2), 70-81.

Kenedi, A. R. Y. K. (2017). Peningkatan Hasil Belajar Siswa Pada Pembelajaran Ipa Dengan Menerapkan Strategi Problem Based Learning Di Sekolah Dasar. Jurnal Ilmiah Pendidikan Guru Sekolah Dasar, 1(1), 17-32. Https://Primary.Ejournal.Unri.Ac.Id/Index.Php/Jpfkip

Komang, N., \& Astini, S. (2020). Tantangan Dan Peluang Pemanfaatan Teknologi Informasi Dalam Pembelajaran Online Masa Covid-19. 3(2), 241-255.

Kumala, F. N. (2017). Pembelajaran Ipa.

Kurniawati, D. (2020). Pengaruh Penggunaan Gadget Terhadap Prestasi Siswa. Edukatif: Jurnal Ilmu Pendidikan, 2(1), 79-84.

Raihan. (2019). Penerapan Reward Dan Punishment Dalam Peningkatan Prestasi Belajar Pendidikan Agama Islam Terhadap Siswa Sma Di Kabupaten Pidie The Implementation Of Rewards And Punishments Within The Islamic Religious Education Learning In Sma ( Public Senior High Schoo. Dayah: Journal Of Islamic Education, 2(1), 115-130.

Roig-Vila, R., Lecturer, S., Didactics, G., Didactics, S., Mengual-Andr, S., Education, C., Quinto-Medrano, P., \& Immersion, S. (2015). Primary Teachers' Technological, Pedagogical And Content Knowledge. $151-159$.

Rosidah, A. (2016). Penerapan Media Pembelajaran Visual Untuk Meningkatkan Pemahaman Konsep Siswa Pada Mata Pelajaran Ips. Jurnal Cakrawala Pendas, 2(2).

Salas-Rueda, R.-A. (2020). Tpack : Technological, Pedagogical And Content Model Necessary To Improve The Educational Process On Mathematics Through A Web Application? International Electronic Journal Of Mathematics Education, 15(1), 1-13.

Sekaringtyas, T. (2017). Laboratorium Ipa Di Sekolah Dasar.

Subakti, H., Prasetya, K. H., Widya, U., Mahakam, G., Balikpapan, U., \& Belajar, M. (2020). Pengaruh Pemberian Reward And Punishment Terhadap Motivasi Belajar Bahasa Indonesia Siswa. Jurnal Basataka, 3(2), 106-117.

Theasy, Y., Bustan, A., \& Nawir, M. (2021). Penggunaan Media Laboratorium Virtual Phet Simulation Untuk Meningkatkan Pemahaman Konsep Fisika Mahasiswa Pada Mata Kuliah Eksperimen Fisika Sekolah. Jurnal Variabel, 4(2), 39-45.

Tuhusula, T. S., Pattana, B., Randai, E., Wateriri, D. R., Walukow, A. F., Tuhusula, T. S., Pattana, B., Randai, E., Wateriri, R., \& Walukow, A. F. (2020). Eksperimen Menggunakan Virtual Lab Berbasis Phet Simulation Dalam Pembelajaran Fisika Pada Materi Gerak Parabola Program Studi Pendidikan Fisika, Universitas Cenderawasih Learning Physics On Parabolic Movement Materials. Jurnal Pendidikan Fisika, 2.

Wisudawati. (2015). Metodologi Pembelajaran Ipa.

Yuliana, Haryadi, A. I. A. (2019). Pengaruh Kompetensi Dan Pelatihan Guru Terhadap Profesionalisme Guru Dengan Mmotivasi Sebagai Variabel Intervening Di Mi, Mts Dan Smk Yayasan Pesantren Darul Abror Kedungjati. 21(2001). 